\title{
気体用熱電温度計
}

\author{
芝亀吉・川 村 幹也 \\ 東洋大学工学部 川越市鯨井字中野台 2100
}

(昭和 46 年 12 月 6 日 受付)

\section{Thermoelectric Thermometer for Gases}

\author{
Kamekichi Shiba and Mikiya Kawamura \\ (Faculty of Engineering, Toyo University, Kawagoe) \\ (Received December 6, 1971)
}

One important and difficult problem in the thermometry of gaseous substances is how to eliminate the error due to radiation.

The purpose of the paper here reported is to construct a thermoelectric thermometer with which the correct temperature of a gas can be obtained by a single measurement regardless of radiation. Two copper-constantan thermopiles are covered with materials of different emissivities. The ratio of the number of couples of the two piles is inversely proportional to the emissivities of the materials.

The error due to radiation is canceled, and the correct temperature of a gas can be obtained by a single measurement. The ratio of emissivities may be estimated experimentally.

Improvements are made for simplification of the equipment and stabilization of the output voltage. The number of couples and reference junctions is considerably reduced.

An improved thermometer of type $I$ is composed of a reflective thermocouple, a reference junction and a set of differential couples.

An improved thermometer of type II is composed of some reflective couples and absorptive couples connected in parallel and a set of compensating differential couples.

The experimental results show that good stability of output voltage and simplification of the setup are obtained fairly well. The error due to radiation is within $\pm 3 \mu \mathrm{V}\left(0.06^{\circ} \mathrm{C}\right)$ over the temperature range from $35^{\circ} \mathrm{C}$ to $45^{\circ} \mathrm{C}$. It is recognized that improved thermometers are available for gas temprature measurement.

\section{1. まえがき}

気体の温度測定は一般にかなり困難である ${ }^{1,2)}$. そ の原因は，つぎのと拈りであると考えられている3゙.

（1）気体の単位体積当たりの熱容量が小さいこと

（2）気体の熱伝導率が一般にかなり小さいこと

（3）温度計の感温部が周团の物体から放射を受け るこど) 6)

この中（1）と（2）とによる困難は温度計の感温 部の単位表面積当たりの熱容量を小さくすることによ って，かなりの程度に軽減される，原因（3）による
困難は, 周囲の物体の温度が被測定気体の温度と同じ でないときに生じる，この放射による影響は，感温部

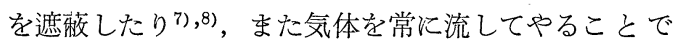
少なくできるが完全ではなく，装置も複雑になる ${ }^{9), 10)}$. 放射の影響を受ける度合の異なる 2 個の感温部を利 用することで放射による影響を消去することがでさる が，これには 2 温度を測定して，グラフなどを利用し て計算することを必要とする.

ここに報告する気体用熱電温度計は上記の方法と同 様の考え方で放射の影響を消去する方式のものである が, 単一量の測定で直接気体の温度が知られるように 
考案されたものである.

\section{2. 測 定 原 理}

放射率がそれぞれ $\sigma_{r}, \sigma_{a}$ の 2 枚の薄板を考光る. その放射率はいずれる既知で， $\sigma_{r}<\sigma_{a}$ であり， $\sigma_{r}$ は なるべく小さく， $\sigma_{a}$ はなるべく大きいことが望まし い. 放射率 $\sigma_{r}$ の薄板を反射薄板, $\sigma_{a}$ のものを吸収薄 板と呼ぶことにする．薄板を考光ることにしたのは， 前揭の（1），（2）に上る困難を避汀るためである. 気体の温度, 反射薄板の温度, 吸収薄板の温度をそれ ぞれ $t^{\circ} \mathrm{C}, t_{r}{ }^{\circ} \mathrm{C}, t_{a}{ }^{\circ} \mathrm{C}$ とする。 $t_{a}{ }^{\circ} \mathrm{C}$ と $t_{r}{ }^{\circ} \mathrm{C}$ との差があ まり大きくないとするので, $\sigma$ と温度 $\theta$ との関係は 直線で表わされる. Fig. 1 はとの例走示す， $\sigma=0$ の

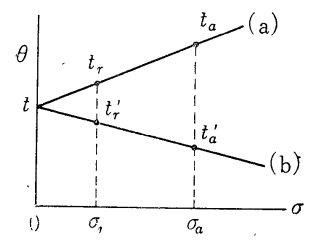

(a) temperature of surrounding bodies $>$ gas temperature

(b) temperature of surrounding bodies $<$ gas temperature

Fig. 1 Emissivity of thermosensitive element vs temperature

ときの温度が，放射の影響を受けない場合の温度，つ まり気体の温度 $t^{\circ} \mathrm{C}$ である.（a） は周囲の物体の温 度が，被測定気体の温度より高い場合であり，（b ) 慅低い場合である。一般に $t_{a}$ と $t$ との差は十分に小 さいとはい光ないが，両薄板を遮蔽して周囲物体から の放射が直接到達しないよらにすると，この差は小さ くなるので, $t$ と $t_{a}$ との間で $\sigma$ と $\theta$ が直線関係に あるとすることができる。ゆえに

$$
\sigma_{a}\left(t_{r}-t\right)=\sigma_{r}\left(t_{a}-t\right)
$$

の関係が得られ，これによって $t_{r}, t_{a}$ の測定で気体自 体の温度 $t$ が知られることになる。

両薄板の温度を熱電温度計で測定することにする。 両熱電温度計の素線は同じ材質のものでもよいが異な っていてもよい，反射薄板拈よび吸収薄板の温度を測 定する温度計をとれぞれ反射温度計持よび吸収温度計 といらことにする。基準接点の温度が $0^{\circ} \mathrm{C}$ のき, 両 温度計の 1 対の熱電対の起電力をそれぞれ $e, e^{\prime}$ とし

温度 $t^{\circ} \mathrm{C}, t_{r}{ }^{\circ} \mathrm{C}$ で $e=e_{t}, e=e_{r}$

温度 $t^{\circ} \mathrm{C}, t_{a}{ }^{\circ} \mathrm{C}$ で $e^{\prime}=e_{t}{ }^{\prime}, e^{\prime}=e_{a}{ }^{\prime}$

であるとする。 $t^{\circ} \mathrm{C} \sim t_{a}{ }^{\circ} \mathrm{C}$ の温度範囲はあまり広くな いので, この範囲内で注温度 $\theta^{\circ} \mathrm{C}$ と $e, e^{\prime}$ とが直線関 係に市ると又られ，

$$
\begin{aligned}
& e_{r}-e_{t}=\varepsilon\left(t_{r}-t\right) \\
& e_{a}^{\prime}-e_{t}^{\prime}=\varepsilon^{\prime}\left(t_{a}-t\right)
\end{aligned}
$$

の関係がある.ここに $\varepsilon, \varepsilon^{\prime}$ は一般には温度によるが,
この範囲内では定数とみられる。

（2）式を（1）式代入して整理すると,

$$
\varepsilon^{\prime} \sigma_{a} e_{r}-\varepsilon \sigma_{r} e_{a}^{\prime}=\varepsilon^{\prime} \sigma_{a} e_{t}-\varepsilon \sigma_{r} e_{t}^{\prime}=E(t)
$$

となる. そこで $E(\theta)$ と温度 $\theta^{\circ} \mathrm{C}$ との関係を示すグ ラフが作られていれば， $e_{a}{ }^{\prime}, e_{r}$ を別々飞測定し，(3) 式の左辺に代入して計算し, その值からグラフによっ て $t$ を求めることができるが，これを単一の測定で求 めることを考光て見る。

\section{$2 \cdot 1$ 基 本 形}

反射温度計および吸收温度計の熱電対列がそれぞれ $n_{r}$ 対括よび $n_{a}$ 対の熱電対からできているとし, $n_{r}$, $n_{a}$ が近似的に

$$
n_{r} \cdot \varepsilon \cdot \sigma_{r}=n_{a} \cdot \varepsilon^{\prime} \cdot \sigma_{a}
$$

の関係沈するうに選定されているとする。 このとき には（3）式は（4) 式により

$$
n_{r} \cdot e_{r}-n_{a} \cdot e_{a}{ }^{\prime}=n_{r} \cdot e_{t}-n_{a} \cdot e_{t}{ }^{\prime}=E(t)
$$

（5）式の左辺は両熱電対列の熱起電力の差である から, 両熱電対列を逆直列飞連結して全体の熱起電力 を測定すれば $E(t)$ が得られる。このように単一測定 とよって気体自体の温度が知られる。

ここで両熱電対列素線について $\varepsilon と \varepsilon^{\prime}$ との比が温 度によらないならば，広い温度範围にわたって（5） 式が充される。しかし一般にはそうではない，そこで， 両熱電対列河一材質の素線を用いると, 常に $\varepsilon=\varepsilon^{\prime}$ であり，(4) 式は

$$
n_{r} \cdot \sigma_{r}=n_{a} \cdot \sigma_{a}
$$

となる、さらに， $e_{t}=e_{t}^{\prime}$ であるから，(5) 式は

$$
E(t)=\left(n_{r}-n_{a}\right) e_{t}
$$

となる。これは $\left(n_{r}-n_{a}\right)$ 対の熱電対の温度 $t^{\circ} \mathrm{C}$ 飞拉 ける熱起電力等しいことを示している.な招実際に は, 反射温度計の熱電対列の中の $\left(n_{r}-n_{a}\right)$ 対炕だけ 基準接点を用い，基準接点の数を節約することができ る.すなわち Fig. 2 飞扮いて全起電力 $E$ は

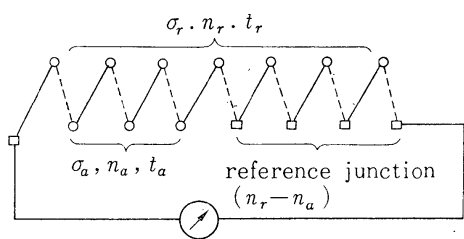

Fig. 2 Connection of thermopiles (basic type)

$$
\begin{aligned}
E & =\varepsilon n_{a}\left(t_{r}-t_{a}\right)+\varepsilon\left(n_{r}-n_{a}\right) t_{r} \\
& =\varepsilon\left(n_{r} t_{r}-n_{a} t_{a}\right)=\varepsilon\left(n_{r}-n_{a}\right) t
\end{aligned}
$$

となる。

\section{$2 \cdot 2$ 改良形 I}

基本形の熱電対の数特よび基準接点数を少なくする ように，また，出力が安定になるように改良する。 
（1）式を

$$
t=t_{r}-\frac{\sigma_{r}}{\sigma_{a}-\sigma_{r}}\left(t_{\alpha}-t_{r}\right)
$$

と書き変兄ることができる.これは 1 個の熱電対 $t_{r}$ と 差動熱電対 $\left(t_{a}-t_{r}\right)$ の起電力を $\sigma_{r} /\left(\sigma_{a}-\sigma_{r}\right)$ 倍した ものを逆直列飞連結すればよいことを示している。こ のときの結線図は Fig. 3 に示されているようになる.

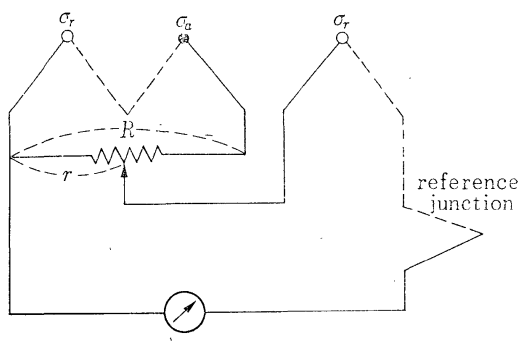

Fig. 3 Improved thermometer of type I (schematic)

十分大きい抵抗 $R$ で差動熱電対を分路し，その一部 $r$ から $t_{r}$ の注らに連結されている。このとき $r$ は

$$
\frac{\sigma_{r}}{\sigma_{a}-\sigma_{r}}=\frac{r}{R} \text {. }
$$

の関係が成り立つように定められる。

つぎに反射熱電対を 1 個でなく $m$ 個を直列化結 する場合を考光る。このときには，(9）式を $m$ 倍 した式

$$
m t=m t_{r}-\frac{m \sigma_{r}}{\sigma_{a}-\sigma_{r}}\left(t_{a}-t_{r}\right)
$$

によって, 反射温度計の熱起電力から， 1 組の差動熱 電対の出力の $m \sigma_{r} /\left(\sigma_{a}-\sigma_{r}\right)$ 倍を引いた残りが, $m$ 個 の熱電対の真温度 $t^{\circ} \mathrm{C}$ に拈ける熱起電力に等しいこ とが知られる。 このときと, $m \sigma_{r} /\left(\sigma_{a}-\sigma_{r}\right)$ が1等 しいよらな整数 $m$ があ机ば，その $m$ については抵 抗分圧器が不用となる. このような整数 $m$ が存在し ないときには，この比がなるべく1に近くて1より小 さいといら条件が充されている整数 $m$ を選定し, 差 動熱電対の起電力を少し減少して補正すればよいので, 抵抗分圧器の代わりに, 適当な 1 個の抵抗で分路すれ ばたりる、また, 直読のために用いる出力減衰器も, 減 衰比が簡単な整数でよいので，正確なものが得やすい．

\section{$2 \cdot 3$ 改良形 II}

基本形にしても改良形 I にしても多くの基準接点を 必要としたり, 分圧器, 減衰器などを用いたりしなけ ればならない，改良形IIは，熱電対の並列接続を利用 する方式で，上記のようなものを必要としない。

一般㳊起電力が $E_{m}$ の電源を $m$ 個, $E_{n}$ の電源を $n$ 個を並列に接続したときの合成起電力 $E$ は，

$$
E=\frac{m E_{m}+n E_{n}}{m+n}
$$

で与兄られる: ただし各電源の内部抵抗は等しいとす る.これを $n_{r}$ 個の反射熱電対と $n_{a}$ 個の吸収熱電対 之を並列淁続する場合に適用すると，(12）式は

$$
E=\frac{n_{r} e_{r}+n_{a} e_{a}}{n_{r}+n_{a}}
$$

となる、いっぽう，(1) 式を書きな洛して

$$
\begin{gathered}
t=\frac{\sigma_{a} t_{r}-\sigma_{r} t_{a}}{\sigma_{a}-\sigma_{r}}=\frac{x t_{r}+y t_{a}}{c\left(\sigma_{a}-\sigma_{r}\right)}-\left(t_{a}-t_{r}\right) \\
\text { と护くと, } x, y \text { は } \\
x=c \sigma_{r}, y=c\left(\sigma_{a}-2 \sigma_{r}\right)
\end{gathered}
$$

で与兄られる。ここで, 比 $x / y$ 亿近似的等しい簡単 な整数比を $n_{r} / n_{a}$ とする。 $n_{r}, n_{a}$ は，あをり大きく ない整数である.

上記の考方に基づいて，Fig. 4 飞示されている.

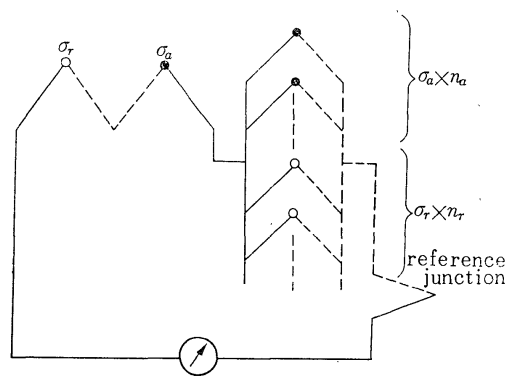

Fig. 4 Improved thermometer of type II (schematic)

ように, $n_{r}$ 個の反射熱電対接点と $n_{a}$ 個の吸収熱電 対接点を並列に接続したものと, 1 組の差動熱電対と を逆直列に連結する。このときの並列熱電対起電力は

$$
\frac{n_{r} e_{r}+n_{a} e_{a}}{n_{r}+n_{a}}=\frac{x e_{r}+y e_{a}}{x+y}=\frac{x e_{r}+y e_{a}}{c\left(\sigma_{a}-a r\right)}
$$

で与兄られるので, 近似的比真温度 $t^{\circ} \mathrm{C}$ が測られる。

\section{3. 実 験 方 法}

上述の考方方に従って試作された気体用熱電温度計 によって，空気の温度が測定されることは理論的佂 明されている．この温度計によって空気の温度が実際 に測定されることを実験的に実証することは，他の方 法で空気自体の温度を測定することが，ほとんど不可 能であるためにはなはだ困難である。

そこで，直接ではないが，空気の温度が測られるこ とを推定するために

（1）差動熱電対による放射の影響の測定

（2）恒温槽内壁の放射影響の測定

(3) 放射率の比 $\sigma_{a} / \sigma_{r}$ の評価

（4）試作気体用温度計による実験 
を行ならこととした。

\section{4. 実 験 装 置}

実験に使用した装置は Fig. 5 の測定系統図版よび， Fig. 6 の写真に示されているようと, 試作気体用熱 電温度計，恒温槽，基準接点，測定部からできている。

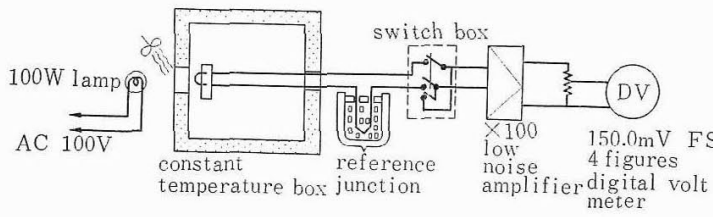

Fig. 5 Schematic figure of measuring system

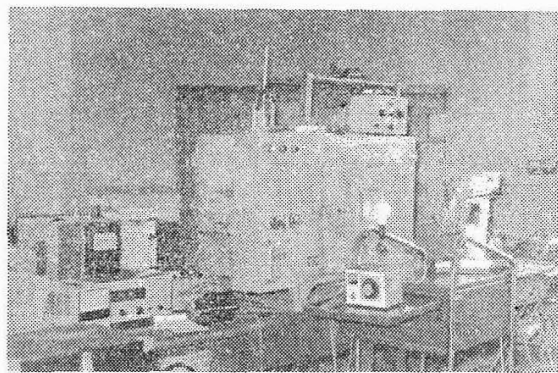

Fig. 6 Photograph of measuring system

\section{$4 \cdot 1$ 試作気体用熱電温度計}

熱電対は Philips 社製銅ーコンスタンタン箔状熱電 対を用い, 吸収温度計には黒インキ染布し, 反射温 度計には市販のアルミ馢を両面接着テープで貼りつけ た. 熱起電力感度は $35 \sim 45^{\circ} \mathrm{C}$ 間ので $42 \mu \mathrm{V} /{ }^{\circ} \mathrm{C}$ であ 乃.

\section{2 恒 温 槽}

容積が $40 \mathrm{~cm}$ 立方で $\pm 0.2^{\circ} \mathrm{C}$ の精度で一定温度が 保をれる (Fig. 7). 小さい二重ガラス密がつけられて

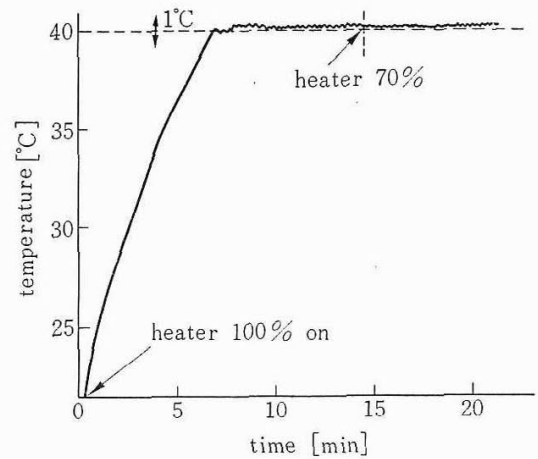

Fig. 7 Performance of constant temperature box いて，その外から $100 \mathrm{~W}$ の白熱電球で照射されるよ らになっている。恒温槽内の空気は扇風機でよく㹂抖 され，槽内壁と空気との平均温度差は $0.4^{\circ} \mathrm{C}$ 々小さく
なっている. また内壁の温度分布も $\pm 0.8^{\circ} \mathrm{C}$ の精度に 保たれる。な打恒温槽外の照射用電球のそばにも扇風 機を扣き，電球からの熱伝尊を防ぐために，中間の空 気を常に流動するようにしてある。

\section{$4 \cdot 3$ 測 定 部}

熱電対出力リード線は恒温槽の上部の小孔から引き 出され，槽の上に扔かれている基準接点用魔法びんと， $E_{0}, E_{r}$ 切換 $\mathrm{SW}$ 箱に接続され, 关の出力は卓上の直 流堌幅器, 減衰器敋経て, 4けたのディジタル電圧計 につながれている。

いち特うの目安として空気の温度を知るために，サ 一ミスタ温度計を恒温槽内に設置した。放射を避ける よらと感温部は遮蔽されているので, 正しい空気温度 に近い值が得られる。

\section{5. 实験とその結果}

\section{$5 \cdot 1$ 差動熱電対による放射影響の測定}

恒温慒内に反射熱電刘接点と吸収熱電刘接点とから なる差動熱電刘置き $50^{\circ} \mathrm{C}$ 上り $40^{\circ} \mathrm{C}$ まで恒温槽内 を䚌汼しながら冷却した場合の差動熱電対出力の恋化 を外部から照射を与光たときと，与克ないときとにつ。 いて測定したところ，Fig. 8 の結果を得た.

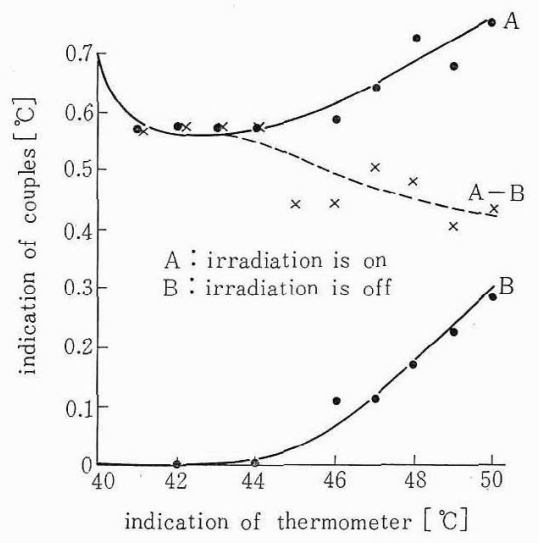

Fig. 8 Effect of irradiation on differential couples

照射を与充ないときのグラフ Bが完全に0でないの は，恒温慒内壁と空気とのわずかの温度美によるもの で祭る。沛觉に照射による影響はA-B で示される。

\section{$5 \cdot 2$ 槽内壁の放射影響の測定}

差動熱電対によって槽内壁の放射の影響が現われる ことがわかったが， $\theta_{a}, \theta_{r}$ そのものがどのような影響 を受けるかをしらべた．Fig. 9 はとの結果で峁り外 部から照射しないで覧拌加熱しながら測った場合と自 然冷却の状態で測った場合とを示す。

\section{$5 \cdot 3$ 放射率比 $\sigma_{a} / \sigma_{r}$ の評価}




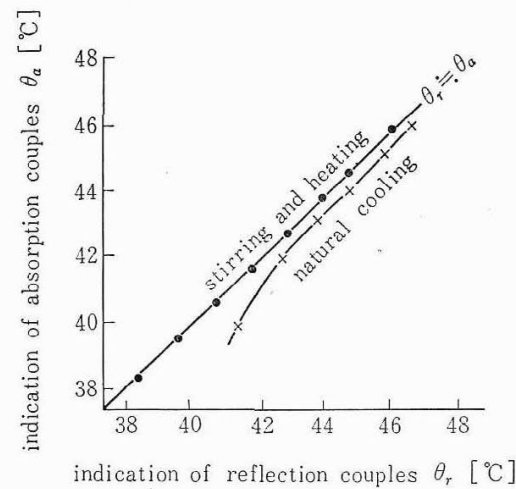

Fig. 9 Comparision of outputs of both couples in a constant temperature box

本実験に使用乙ている表面材料の放射率比の実測法 を考党る.ここで $\sigma_{a}, \sigma_{r}$ の絶対值の測定は困難であ り，また必ずしむ必要ではなく，此 $\sigma_{a} / \sigma_{r}$ がわか机ば

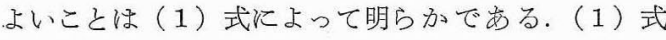
より

$$
\sigma_{a} / \sigma_{r}=\left(t_{a}-t\right) /\left(t_{r}-t\right)
$$

で荡るが，照射しないときの熱電対起電力が $E_{a}=E_{r}$ ならば,これは真温度 $t$ をしていることになるので 照射を与光たときの起電力 $E_{a}{ }^{\prime}, E_{r^{\prime}}{ }^{\prime}$ より

$$
\frac{\sigma_{a}}{\sigma_{r}}=\frac{E_{a}{ }^{\prime}-E_{a}}{E_{r}{ }^{\prime}-E_{r}}=\frac{\Delta E_{a}}{\Delta E_{r}}
$$

となり， $\sigma_{a} / \sigma_{r}$ が知られる。

結果は Fig. 10 亿示されて数り， $\Delta E_{a} / \Delta E_{r}$ が 2.5

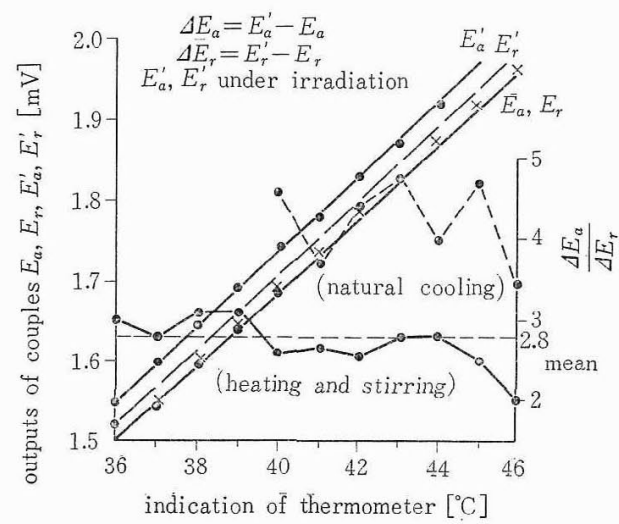

Fig. $10 \Delta E_{a} / \Delta E_{r}$ vs temperature

〜3 で平均 2.8 となった。

\section{$5 \cdot 4$ 試作熱電対による実験}

（1）基本型 $\quad \sigma_{a} / \sigma_{r}=3$ 之想定して 4 個の熱電 対を, Fig. 11 および Fig. 12 の写真に示されてい るよらに，基板にマウントしたものを用いた。この場 合の出力は，乞の温度に䄧ける熱起電力の 2 倍で每る から, 出力增幅器の後の減衰器で $1 / 2$ にして, その温

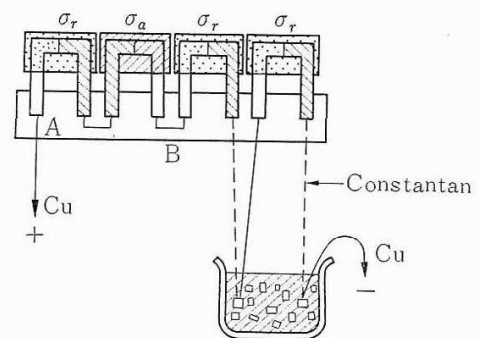

Fig. 11 Construction of trial thermometer (basic type)

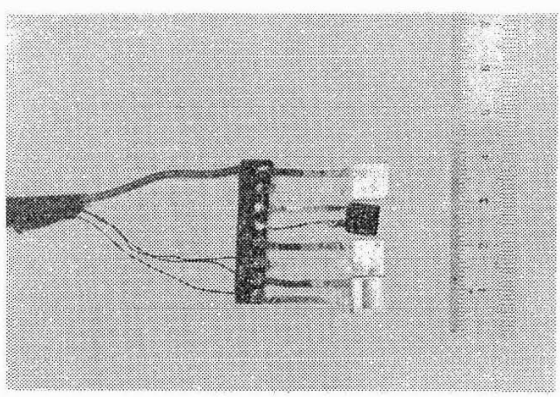

Fig. 12 Photograph of trial thermometer Fig. 11

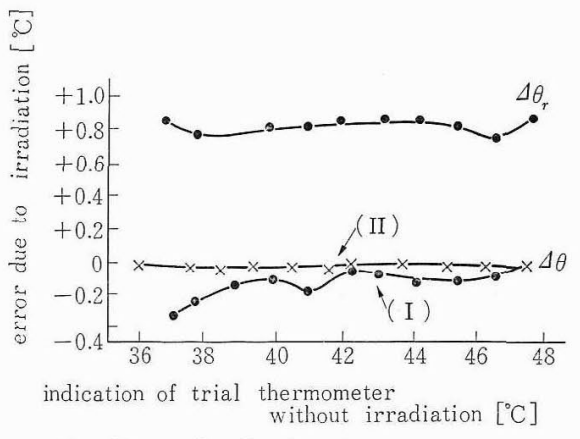

$\Delta \theta_{r}$ : Error of reflective thermometer $\Delta \partial:$ Error of trial thermometer

(I) basic type

(II) type adjusted by parallel resistor

Fig. 13 Error $\Delta \theta$ of trial thermometer

度に捛ける起電力定直読できるようにした。

Fig. 13 ほ气の結果で，照射しないとさの指示に対 し，照射したときどれだけの誤差を生じるかを示して いる. $\Delta \theta$ の（I）が实験の場合で, 放射誤差は -0.2 ${ }^{\circ} \mathrm{C}$ までに減少している. $\Delta \theta_{r}$ は Fig. 11 の $\mathrm{A} \sim \mathrm{B}$ 間 を短絡して補正起電力を除いた場合で， $0.8^{\circ} \mathrm{C}$ の誤差 を生じで招り，明らかにこの形の效果が現われている。 さらに $\mathrm{AB}$ 間堂抵抗で分路して調整した場合につい て, $\Delta \theta$ の (II) のグラフに示されるように, -0.06 ${ }^{\circ} \mathrm{C}$ 以下になった.

（2）改良形 I 2 個の反射熱電刘之 1 個の吸収 熱電対々を，Fig. 14 に示されているように基板にと 


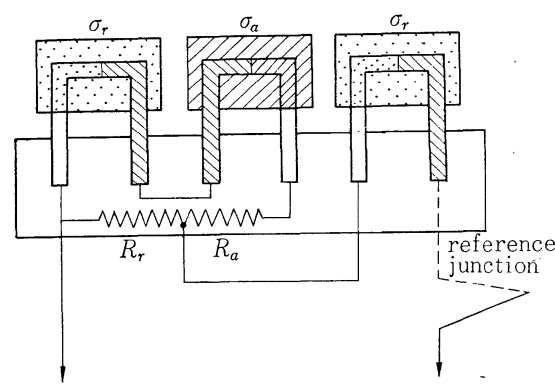

Fig. 14 Improved thermometer of type I (actual)

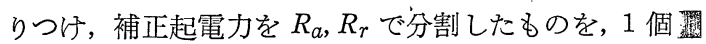
の反射熱電対起電力 $e_{r}$ に加えるようになっている.

$\sigma_{a} / \sigma_{r}=3$ ならば $R_{a}=R_{r}$ である. 実際に $R_{a}=R_{r}=$ $1.5 \mathrm{k} \Omega$ としたところ， $\Delta \theta=+0.25^{\circ} \mathrm{C}$ となり，補償不 足とみられたので， $R_{a}=820 \Omega ， R_{r}=1.5 \mathrm{k} \Omega$ としたと ころ; Fig. 15 に示されるように, $\Delta \theta$ は $-0.07^{\circ} \mathrm{C}$ 以 内となった：この場合 $\sigma_{a} / \sigma_{r}=2.5$ に相当した.

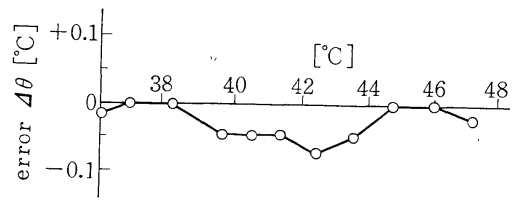

Fig. 15 Error of improved thermometer of type I

（3）改良形 II （14）式は

$$
\begin{aligned}
& \frac{\sigma_{a}}{\sigma_{r}}=3 \text { のとき } t=\frac{t_{r}+t_{a}}{2}-\left(t_{a}-t_{r}\right) \\
& \frac{\sigma_{a}}{\sigma_{r}}=2.5 \text { のとき } t=\frac{2 t_{r}+t_{a}}{3}-\left(t_{a}-t_{r}\right)
\end{aligned}
$$

となり，結線図はそれぞれ Fig. 16, Fig. 17 となる.

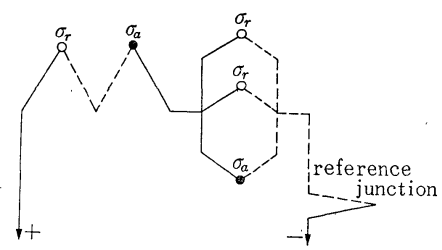

Fig. 16 Connection of improved thermometer of type II A

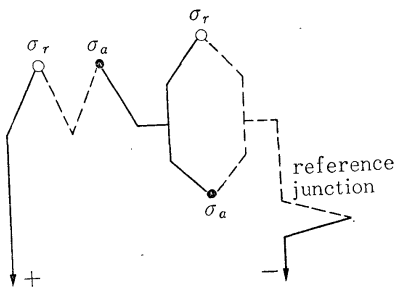

Fig. 17 Connection of improved thermometer of type II B

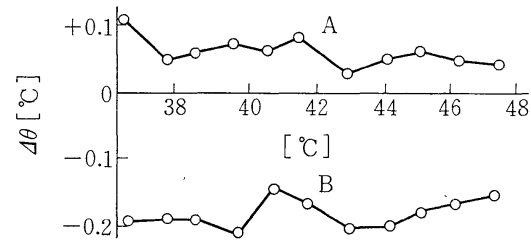

Fig. 18 Error of improved thermometer of type II A, B

また実験結果は Fig. 18 に示されるように，照射誤 差は，とれぞれ $+0.05^{\circ} \mathrm{C},-0.17^{\circ} \mathrm{C}$ となった。 な报, 用いた熱電対は，すべて4.1に述べた同一規格，寸法 のものであるので，その内部抵抗は，ほぼ等しいとみ なされる。

\section{6. 考察}

基本形, 改良形いずれも照射誤差を $0.1^{\circ} \mathrm{C}$ 以下に括 さえることができて，十分実用的精度を示したが，基 本形では多くの熱電対执よび基準接点が必要であり, 測定のために引き出すリード線が長くなって, 種々の 雑音を拾いやすく，安定度が十分でない。

改良形 I では放射率に無関係に熱電対 1 個に相当す る出力を取り出すので, 基準接点 1 個で足り, 装置が 簡単になる．また補償用の抵抗を調整することによっ て，精度を平均 $0.03^{\circ} \mathrm{C}$ までげることができる。し かし，抵抗は雑音の少ない良質のものを使用しなけれ， ばならない，この実験中に抵抗雑音によると考光られ る出力の不安定が多少認められた.

改良形 II では， $\sigma_{a} / \sigma_{r}$ の值によっては多数の熱電対 を要する点は基本形と同様であるが，基本形よりは，

$$
\left(n_{a}+n_{r}\right)-\left(n_{r}-n_{a}+2\right)=2\left(n_{a}-1\right)
$$

だけ少なくてすむ，谷のら基準接点は 1 個でたりる。 分圧抵抗器は不要である.

$\sigma_{a} / \sigma_{r}$ の正しい值は容易に知られないことが多い. しかしだいたいの值の推定は容易である，その推定值 が真の值と $20 \%$ ちがっているときでも, 誤差は 0.2 ${ }^{\circ} \mathrm{C}$ の程度となるにすぎない。

\section{7. 結論}

熱電対温度計で気体温度を測定するさいに，外部物 体からの放射の影響に対する補償を行ない, 真温度を 知るために, 放射率の異なる材料で蔽った 2 種の熱電 対接点と組み合わせる方法を考究した。

まず基本形として, 感温接点が放射率の異なる材質 で被覆された 2 種の熱電対を，それぞれの放射率に反 比例した数だけ使用して，それを逆直列に連結したも のを試みた. その結果として放射による平均誤差を 
$35 \sim 45^{\circ} \mathrm{C}$ の範囲で $0.1^{\circ} \mathrm{C}$ 以下に怙さめることができ た.

つぎに基本形を改良して，熱電対の数㧊よび基準接 点の数を減らして，装置の簡易化と出力の安定化とを 企図した方式のものを研究した.

改良形 $\mathrm{I}$ は，反射熱電対 1 個，基準接点 1 個，差動 熱電対 1 組とを使用し, 差動熱電対で得られる起電力 を分圧抵抗器で調整して補償起電力を得る方式のもの である。

改良形Iは，並列熱電対を用いて，その平均熱起電 力を 1 組の差動熱電対の出力で補償する方式のもので ある。

改良形 I 抒よびIIを試作し実験した結果，装置の簡 易化と出力の安定化が，かなりの程度に実現されるこ

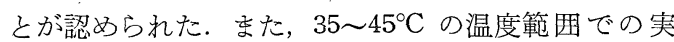
験によって，照射による誤差がいずれのものとも， $\pm 0.06^{\circ} \mathrm{C}$ 以内になって扮り, 気体の温度測定に使用 できることが確認された、な初照射条件等が実験以外 の一般的な場合にも，十分に有効であると考学られる。

\section{参考文献}

1) Measuring Air Temperature, Electrical Times 145 [1], p. 23 (1964)

2) L.C. Lynnworth : Sound Ways to Measure Temperature, Instrumentation Technology, 16[4], 47/52 (1969)

3）宮内 - 林 - 渡辺 - 杉山共著 : 温度測定並自動制御, p. 32 (コロナ社)

4) M. Mikheyev : Fundamentals of Heat transfer, Chap. 12, Peace Publishers Moscow

5) W. H. Giedt : Principles of Engineering Heat Transfer, Chap. 12, Nostrand (1957)

6) M. Jakob : Heat Transfer, VI p. 23, Wiley (1965)

7) E.F. Snyder et al. : Thermal Radiation Shields, Instruments \& Control Systems, Vol. 39, 101/106 (1966)

8) R.J.Moffat:Gas Temperature Measusement, Direct Design of Radiation Shielding, ISA Trans., 8 [2] 91/97 (1969)

9) 3) p. 100

10) P.Euser : Compensation Pyrometer for the Measurement of Surface Temperature of Moving Parts Independent of the Surface Emissivity, Instrument Practice, 17 [5], 487/489 (1963) 